\title{
PENERAPAN GAYA MENGAJAR INKLUSI MENGGUNAKAN MEDIA MODIFIKASI UNTUK MENINGKATKAN HASIL BELAJAR TOLAK PELURU PADA SISWA KELAS IX SMP N 1 SOSA KABUPATEN PADANG LAWAS TAHUN AJARAN 2015/2016
}

\author{
Zen Fadli \\ Ardiansyah Harahap \\ Fakultas Ilmu Keolahragaan, Universitas Negeri Medan, Medan, Indonesia \\ Correspondence: Fakultas Ilmu Keolahragaan, Universitas Negeri Medan, Medan, \\ Indonesia. E-mail:
}

\begin{abstract}
Abstrak
Penelitian ini bertujuan untuk mengetahui Peningkatkan Hasil Belajar Tolak Peluru dengan gaya mengajar inklusi menggunakan media yang dimodifikasi Pada Siswa Kelas $I_{2} S M P$ Negeri Sosa padang Lawas Tahun Ajaran 2015/2016.Penelitian ini adalah siswa kelas IX 2 yang menjadi sampel dengan jumlah siswa sebanyak 30 siswa yang akan diberikan tindakan berupa pembelajaran tolak peluru dengan gaya inklusi menggunakan media yang dimodifikasi. Metode yang dipakai pada penelitian ini adalah Penelitian Tindakan Kelas (Classroom Action Research). Untuk memperoleh data dalam penelitian ini dilakukan tes hasil belajar di akhir setiap siklus yang berbentuk aplikasi penilaian teknik dasar dasar tolak peluru. Dengan pelaksanaan penelitian tes hasil belajar ini dilaksanakan selama dua minggu atau dua kali pertemuan. Analisis data dilakukan dengan reduksi data dan paparan data. Setelah data terkumpul akan dilakukan analisis : (1) dari tes hasil belajar siklus I diperoleh sebanyak 20 orang siswa dengan nilai setelah dikonfersikan sebesar (66,6\%) telah mencapai tingkat ketuntasan belajar sedangkan 10 orang siswa (33,4\%) belum mencapai tingkat ketuntasan belajar. Dengan nilai rata-rata hasil belajar setelah adalah 71,04. Namun belum memenuhi kriteria ketuntasan secara klasikal yang diharapkan yaitu 85\%. (2) dari tes hasil belajar siklus II diperoleh data sebanyak 27 orang siswa dengan nilai setelah dikonfersikan sebesar (90\%) yang telah mencapai ketuntasan dalam belajar dan 3 orang siswa (10\%) masih belum tuntas. Dengan nilai rata-rata hasil belajar setelah adalah 77.08. Berdasarkan hasil analisis data dapat dikatakan bahwa dengan gaya mengajar inklusi menggunakn media yang dimodifikasi dapat memberikan peningkatan terhadap proses hasil belajar tolak Peluru dada pada siswa kelas IX SMP Negeri 1 Sosa Padang Lawas Tahun Ajaran 2015/2016.
\end{abstract}

\section{Kata Kunci: Modifikasi Untuk Meningkatkan Hasil Belajar Tolak Peluru}

\section{Pendahuluan}

Pendidikan merupakan kebutuhan sepanjang hayat. Setiap manusia membutuhkan pendidikan, sampai kapan dan dimanapun ia berada. Pendidikan sangat penting artinya, sebab tanpa pendidikan manusia akan sulit berkembang dan bahkan akan terbelakang. Dengan demikian pendidikan harus betul-betul diarahkan untuk menghasilkan manusia yang 
berkualitas dan mampu bersaing, di samping memiliki budi pekerti yang luhur dan moral yang baik.

Berdasarkan hasil pengamatan yang penulis lakukan di SMP Negeri 1 Sosa Padang Lawas pada jam pelajaran Penjas, peralatan yang ada disekolah itu terbatas hanya ada 1 peluru untuk putra dan 1 peluru untuk putri, lapangan disana juga luas, tetapi yang bisa digunakan untuk materi tolak peluru hanya sedikit. masih banyak di temukan siswa yang mengalami kesulitan pada teknik Tolak peluru, hal itu terbukti banyak siswa yang belum memahami teknik yang kurang tepat. Informasi yang diperoleh dari guru Penjas dari 30 siswa yang ada dikelas IX hanya ada 15 siswa yang paham tentang teknik tersebut. Berarti dari data tersebut sekurangnya hanya sekitar $50 \%$ dari jumlah siswa yang ada, yang berhasil memahami teknik Tolak peluru yang benar dengan KKM 75, Namun nilai itu belum memenuhi kriteria ketuntasan minimal secara klasikal yang ditetapkan sekolah yaitu sekitar $85 \%$ dari keseluruhan siswa.

Belum diketahui secara pasti penyebab dari kesulitan siswa untuk melakukan teknik Tolak Peluru dengan baik. Mungkin karena kurang jelasnya penjelasan yang diberikan guru mengenai teknik Tolak Peluru tersebut kurang perhatian siswa mengenai teknik tersebut . Untuk itu diperlukan suatu cara agar siswa dapat menguasai teknik dasar tolak Peluru dengan benar sehingga akan menghasilkan proses pembelajaran yang maksimal. Jika selama ini guru pendidikan jasmani menyajikan materi pelajaran Tolak peluru lewat informasi buku dan contoh (peragaan) maka pada kesempatan kali ini guru menyajikan melalui memodifikasi media pembelajaran.

Berdasarkan uraian di atas penulis merasa tertarik untuk menerapkan gaya mengajar yang lain. Salah satu gaya mengajar yang dapat digunakan adalah gaya mengajar Inklusi. Gaya inklusi/cakupan pada prinsipnya adalah memberikan bentuk tugas yang sama dengan tingkat kesulitan yang berbeda. Dari bentuk gaya ini diharapkan mampu menjadi masukan dan cara alternatif lain dalam penggunaan dan penerapan gaya mengajar pendidikan jasmani di sekolah-sekolah. Sehingga pelaksanaan belajar mengajar itu sendiri lebih bervariasi serta mampu menumbuhkan minat, motivasi dan kreativitas. Melalui penerapan gaya mengajar inklusi, diharapkan siswa dapat memahami dan melakukan gerakan tolak peluru dengan benar sesuai rangkaian dan penerapan gaya mengajar inklusi.

Dari uraian diatas maka penulis tertarik ingin melaksanakan penelitian dengan judul “ Penerapan Gaya Mengajar Inklusi Menggunakan Media Modifikasi Untuk Meningkatkan Hasil Belajar Tolak Peluru Pada Siswa Kelas IX SMP N 1 Sosa Kabupaten Padang Lawas Tahun Ajaran 2015/2016.

Penelitian ini bertujuan untuk mengetahui apakah terdapat peningkatan pengaruh gaya mengajar inklusi menggunakan Media Modifikasi dalam meningkatkan hasil belajar tolak peluru siswa kelas IX SMP Negeri 1 Sosa Padang Lawas Tahun Ajaran 2015/2016. Adapun manfaat penelitian ini diharapkan :

1. Memperkaya ilmu pengetahuan tentang gaya mengajar inklusi dan media modifikasi 
2. Untuk guru pendidikan jasmani hasil penelitian ini dapat merupakan umpan balik dalam menentukan gaya mengajar yang tepat dalam menyajikan suatu materi.

3. Untuk memberikan penjelasan tentang pengaruh gaya mengajar dalam mencapai tujuan pembelajaran.

\section{Metode}

Metode penelitian ini adalah penelitian tindakan kelas (Classroom Action Research). Pendekatan yang digunakan adalah pendekatan kualitatif yang berguna untuk mengungkapkan kesulitan belajar siswa dalam proses pembelajaran penjas serta cara mengatasi kesulitan-kesulitan tersebut sebagai upaya untuk meningkatkan hasil belajar siswa pada materi Tolak Peluru. Penelitian ini dilakukan di SMP Negeri 1 Sosa, Kecamatan Padang Lawas Tahun Ajaran 2015/2016. Penelitian ini dilaksanakan pada bulan Desember 2015. Subjek dalam penelitian ini adalah kelas IX $^{2}$ dengan jumlah 30 siswa yang terdiri dari 16 putra dan 24 putri. Objek penelitian ini adalah gaya mengajar inklusi menggunakan media modifikasi tolak peluru pada siswa kelas IX SMP N 1 Sosa Kabupaten padang lawas Tahun Ajaran 2015/2016.

Sesuai dengan jenis penelitian ini, yaitu penelitian tindakan kelas maka penilitian ini akan dilakukan dalam beberapa tahap yang berupa siklus tapi sebelum masuk ke siklus terlebih dahulu melakukan kegiatan di bawah ini :

Gambar 1

SKEMA SIKLUS DALAM PENELITIAN TINDAKAN KELAS

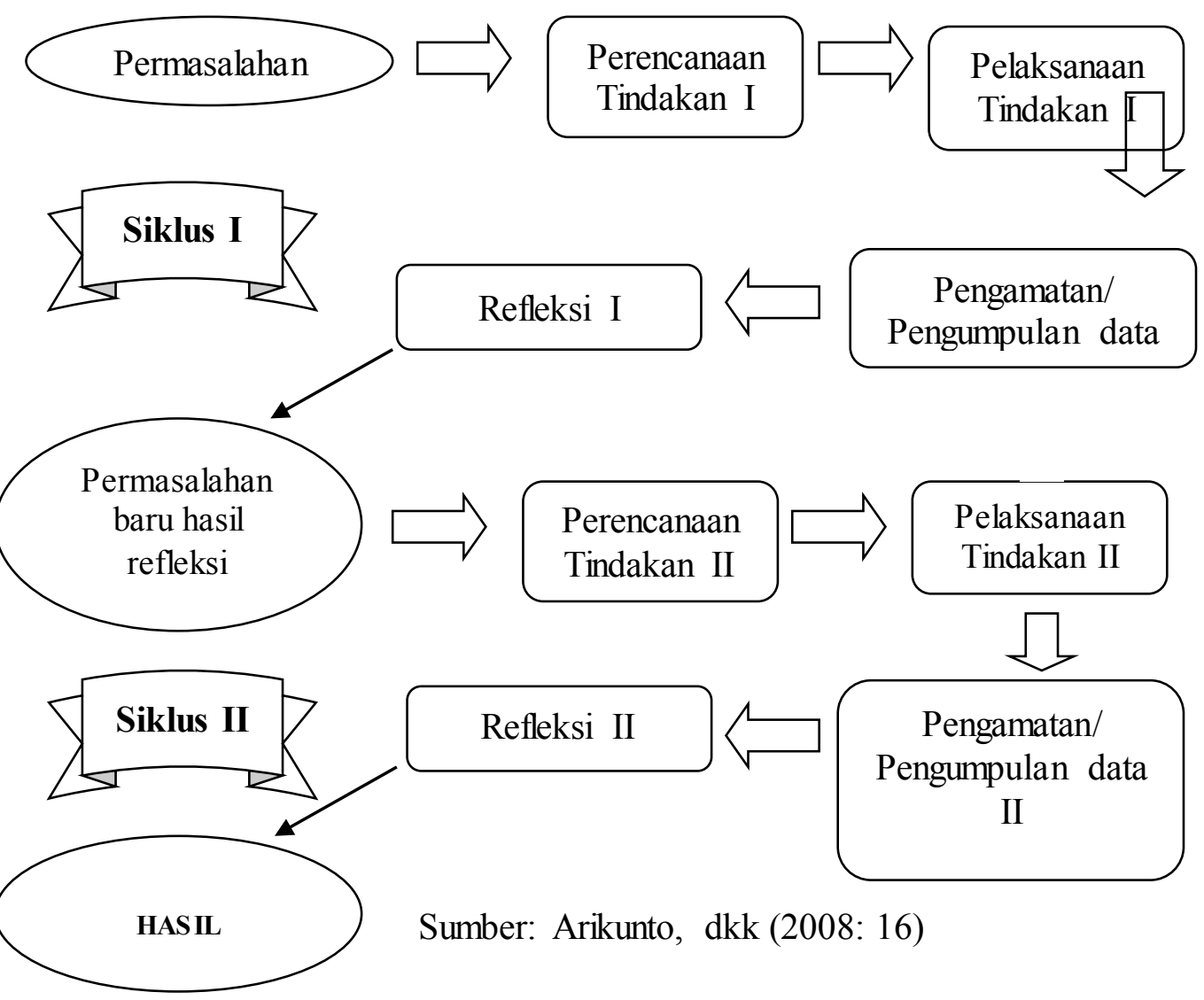




\section{Hasil}

Tindakan yang dilakukan adalah melakukan pembelajaran melalui penguatan umpan balik menggunakan gaya mengajar inklusi dengan media modifikasi pada siswa kelas IX SMP Negeri 1 Sosa Kab. Padang Lawas Tahun Ajaran 2015/2016. Setelah disusun perencanaan dan pelaksanaan, maka akan dapat diketahui haisl dari observasi dan refleksi pada siklus I.

Dari tes analisis yang dilakukan bahwa telah terjadi peningkatan kemampuan siswa. Peningkatan ini terjadi setelah diberikan pembelajaran dengan gaya inklusi yang dirancang pada siklus II yang beracuan pada pengalaman siklus I. peningkatan nilai rata-rata hasil belajar siswa dari tes sebelumnya, yaitu sebesar 6,04 dan peningaktan ketuntasan klasikal sebesar 23,4\%. Setelah diberikan siklus II yang dapat terlihat meningkat. Dari 30 siswa terdapat 27 siswa (90\%) yang telah mencapai ketuntasan belajar. Sedangkan 3 siswa $(10 \%)$ belum mencapai ketuntasan belajar dengan nilai rata-rata hasil belajar siswa 77,08 berarti meningkat dari hasil sebelumnya.

\section{Pembahasan}

Berdasarkan hasil observasi yang telah dilakukan dalam dua siklus kegiatan pelaksanaan tindakan kelas diperoleh data bahwa aktivitas atau keaktifan siswa dalam mengikuti kegiatan pembelajaran mengalami kenaikan pada siklus I presentase keaktifan siswa adalah $75 \%$ sedangkan pada siklus II menjadi 92\%.

Hal ini disebabkan karena proses belajar dan alat yang digunakan dalam pembelajaran kurang terbiasa mereka lakukan, karena dilapangan biasanya mereka menggunakan peluru asli dan proses belajar biasa saja. Guru melakukan dan siswa mengikuti sehingga siswa kurang aktif mengikuti. Sedangkan di siklu II siswa lebih terarah melakukan pembelajran dan guru juga menyesuaikan proses pembelajaran menggunakan gaya inklusi dan alatnya dimodifikasi dengan tingkat kesulitan yang dialami dengan perhatian yang cukup oleh guru.

\section{Kesimpulan}

Berdasarkan hasil belajar siswa maka dapat ditarik kesimpulan bahwa dengan gaya mengajar Inklusi menggunakan media yang dimodifikasi dapat meningkatkan hasil belajar tolak peluru pada siswa kelas IX SMP Negeri 1 Sosa Padang Lawas Tahun Ajaran 2015/2016".

\section{Referensi}

Agung, Sunarno, Evaluasi Hasil Belajar Pendidikan Jasmani. Medan: Diktat perkuliahan FIK Universitas Negeri Medan, 2005.

Djamarah, Belajar dan pembelajaran. Jakarta: PT.Gramedia Pustaka Umum, 2002. 
Husdarta dkk, Belajar dan pembelajaran. Jakarta: Departemen Pendidikan Nasional Direktorat Pendidikan Dasar dan Menengah Bagian Proyek Penataran Guru SLTP setara D-III, 2000.

Kamus Besar Bahasa Indonesia, KBBI, Jakarta: Departemen pendidikan Nasional Direktorat Jendral Pendidikan tinggi Proyek Pembinaan Tenaga Kependidikan, 2005. Lutan R, Strategi Belajar Mengajar Penjaskes. Jakarta: Depdiknas Dirjen Pendidikan Dasar Dan Menengah Bagian Proyek Penataran Guru SLTP Setara D-III, 2000.

Muhibbinsyah, Psikologi Pendidikan. Bandung: Remaja Rosdakarya, 2010.

Muska, musston, Teaching Physical Education. Jakarta: UNJ, 2000.

Rusli dkk, Supervisi Pendidikan Jasmani. Jakarta: Direktorat Jendral Pendidikan dasar dan menengah, 2004.

Slameto, Belajar dan Faktor-Faktor yang Mempengaruhi. Jakarta: Rineka Cipta, 2003.

Suharsimi, Arikunto, Prosedur penelitian Suatu Pendekatan Praktik. Jakarta: Asdi Mahasatyata, 2006.

Tim Penyusun. Pedoman Penulisan Skripsi. Medan: FIK-UNIMED, 2007. 